\title{
Nannobiostratigraphy of the Lower Part of Shiranish Formation, Sinjar Anticline, NW Iraq
}

\author{
Omar Ahmed Al-Badrani \\ Department of Geology \\ College of Science \\ Mosul University
}

(Received 20/12/2011, Accepted 31/3/2011)

\begin{abstract}
Fifteen samples from the lower part of Shiranish Formation, Sinjar anticline, northwest Iraq, are investigated in order to identify calcareous nannofossils species of which twelve species are recorded as follow; one species of holococcoliths, seven are heterococcoliths and four are nannolith. On the basis of the above assemblages two biozones are proposed from oldest (at bottom) to youngest (at top):

2- Tranolithus phacelosus Interval Zone(Part) (CC23)

1- Lithraphidites praequadratus Partial Zone(Part) (CC22)

The above biozones are correlated with other calcareous nannofossils biozones from regional view led to conclude that the section is late Campanian in age.

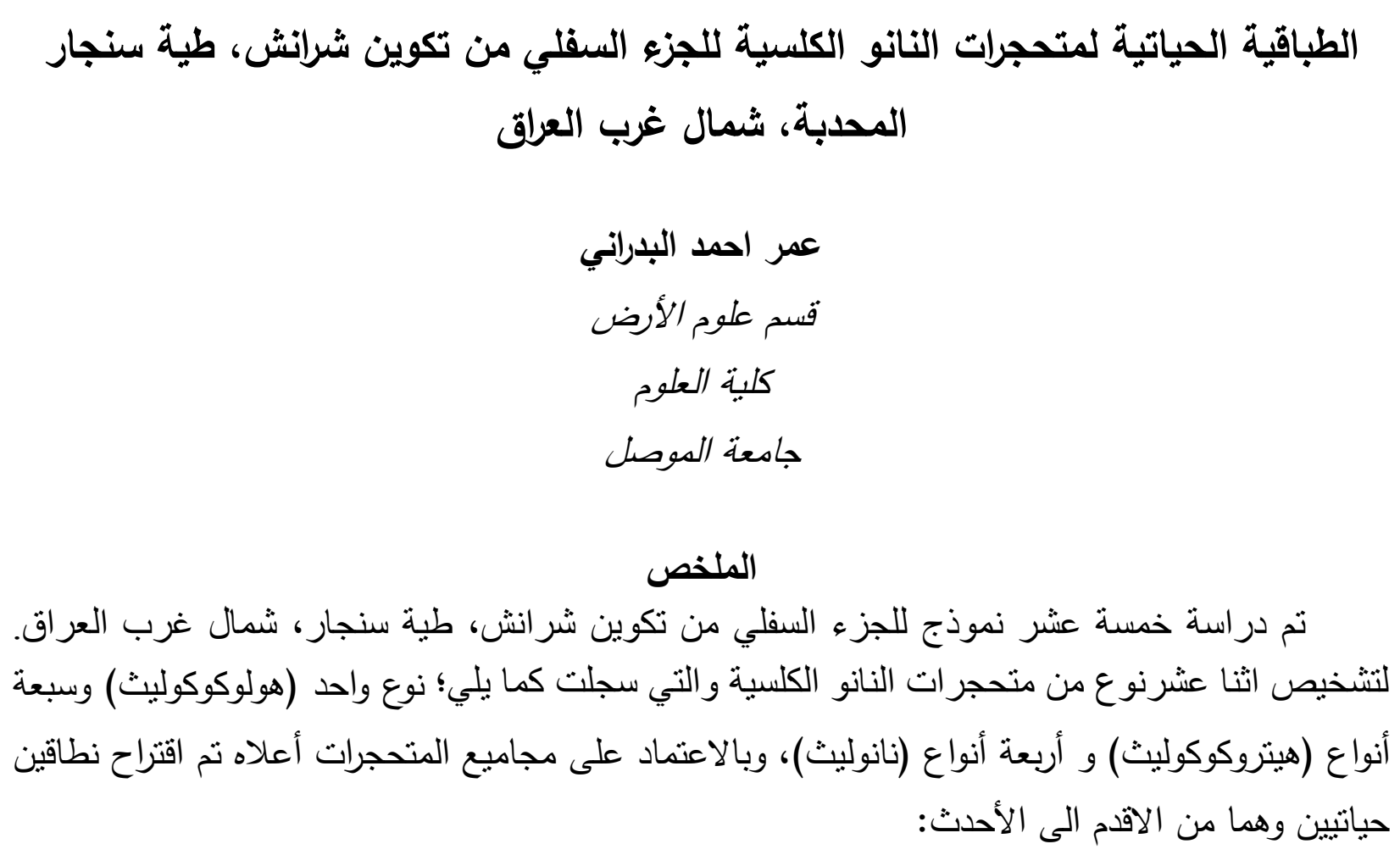


2- Tranolithus phacelosus Interval Zone(Part) (CC23)

1- Lithraphidites praequadratus Partial Zone(Part) (CC22)

تم مضاهاة النطاقين اعلاه مع انطقه متحجرات النانو الكلسية اقليميا حيث تبين بان عمر المقطع المدروس هو الكامبانيان المتأخر.

\title{
INTRODUCTION
}

The Shiranish Formation was first described by (Henson, 1940 in Bellen et al., 1959) from the High Folded Zone of North of Iraq, near the village of Shiranish Islam, Northeast of Zakho. It is belongs to the most widespread units of the Upper Campanian- Maastrichtian cycle in North Iraq.

The studied section exposed at the core of Sinjar anticline, northwest Iraq, which belongs to the Foothill Zone of the Unstable Shelf of the Nubio-Arabian platform (Buday and Jassim, 1987). The present study deals with the exposed stratigraphic successions (15 samples of Shiranish Formation), limited between $36^{\circ} 22^{\prime} 45^{\prime \prime} \mathrm{N}, 41^{\circ} 41^{\prime} 25^{\prime \prime} \mathrm{E}$ and $36^{\circ} 22^{\prime} 54 \mathrm{~N}, 41^{\circ} 41^{\prime} 11^{\prime \prime}$ (Fig.1), consists of well beded blue marly limestone with two bed of conglomerate beds $(10-15 \mathrm{~cm}$.) in the upper part of studied section.

\section{Systematic Paleontology}

The describtion of calcareous nannofossils species based on Young and Bown (1997) as follows :

\author{
Kingdom Protista
}

Class Coccolithophyceae

Family Arkhangelskiellaceae Bukry, 1969

Genus Arkhangelskilla Vekshina, 1959

Type species : Arkhangelskilla cymbiformis Vekshina, 1959

Arkhangelskilla cymbiformis Vekshina, 1959

Pl. 1, Fig. 1

Description: Heterococcoliths, placolith coccoliths with central area filled by a perforate plate divided by axial sutures. The shields are typically bright in cross polarized light. 1-2 distal shield cycles; bright unicycle LM image. 


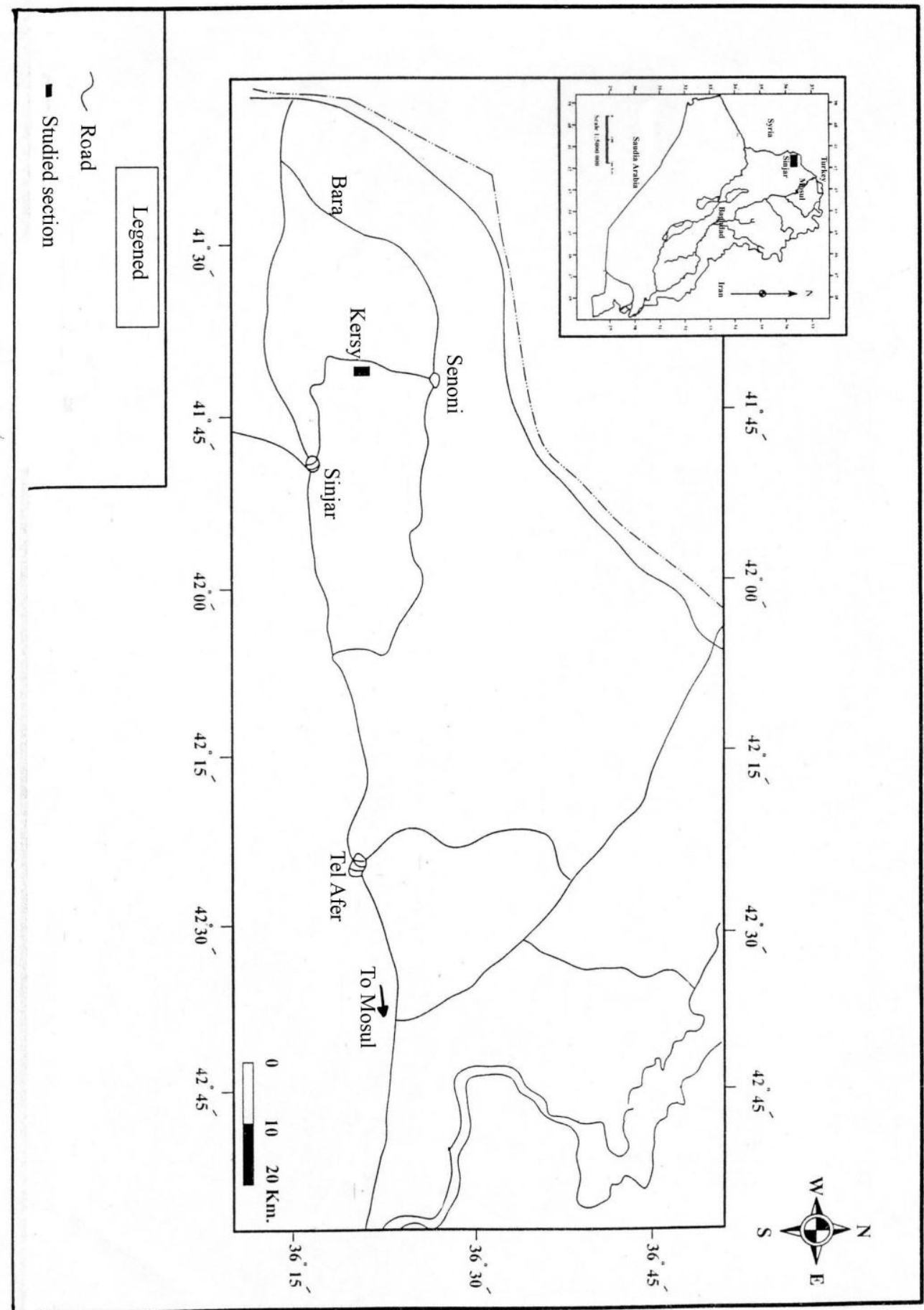

Fig. 1: Location Map of Studied Section. 
Occurrences:

\begin{tabular}{|c|c|c|}
\hline Authors & Age & Location \\
\hline $\begin{array}{c}\text { Vekshina, 1959 } \\
\text { Bramlette and Martini, } \\
1964\end{array}$ & Maastrichtian & Siberia \\
\hline Gartner, 1968 & Maastrichtian & $\begin{array}{c}\text { type of } \\
\text { Maastrichtian }\end{array}$ \\
\hline Perch-Nielsen, 1985 & $\begin{array}{c}\text { Denmark, France, } \\
\text { Tunisia, U.S.A. } \\
\text { Maastrichtian }\end{array}$ & World Wide \\
\hline $\begin{array}{c}\text { Wanderley and Aguiar, } \\
\text { 2006 }\end{array}$ & $\begin{array}{c}\text { Campanian to } \\
\text { Maastrichtian }\end{array}$ & Atlantic \\
\hline Tantawy et al., 2001 & $\begin{array}{c}\text { Campanian to } \\
\text { Maastrichtian }\end{array}$ & Egypt \\
\hline Chira et al., 2004 & $\begin{array}{c}\text { Upper } \\
\text { Cretaceous }\end{array}$ & Romania \\
\hline
\end{tabular}

\section{Arkhangelskilla sp.}

Pl. 1, Fig. 2

Description: Heterococcoliths, placolith coccoliths with central area filled by a perforate plate. The shields are typically bright in cross polarized light. 1-2 distal shield cycles; bright unicycle LM image. The sutures of central area are not clear, therefore the species left under open name.

\section{Occurrences:}

\begin{tabular}{|ccc|}
\hline Authors & Age & Location \\
Present work & Late Campanian & Iraq \\
\hline
\end{tabular}

Family Calyptrosphaeraceae Boudreaux and Hay, 1969

Genus Calculites Prins and Sisingh in Sissingh, 1977

Type species: Calculites ovalis (Stradner, 1963) Prins and Sisingh in Sissingh, 1977

Calculites obscurus (Deflandre, 1959) Prins and Sisingh in Sissingh, 1977 Pl. 1, Fig. 3

Description: Holococcolith, proximal plate of four blocks, ridged and pitted distil surface, narrow and hollow spines. 


\section{Occurrences:}

\begin{tabular}{|c|c|c|}
\hline Authors & Age & Location \\
\hline Deflandre,1959 & $\begin{array}{l}\text { Santonian to } \\
\text { Campanian }\end{array}$ & France \\
\hline Perch-Nielsen,1985 & $\begin{array}{l}\text { Santonian to } \\
\text { Maastrichtian }\end{array}$ & World Wide \\
\hline
\end{tabular}

Family Eiffellithaceae Reinhardt, 1965

Genus Eiffelithus Reinhardt, 1965

Type species: Zygolithus turriseiffeli Deflandre, 1954

Eiffelithius eximius (Stover, 1966) Perch- Nielsen, 1969

Pl. 1, Fig. 4

Description: Heterococcoliths, Loxoliths with crossbars generally fibrous and spine-bearing, central area is perforate.

Occurrences:

\begin{tabular}{|c|c|c|}
\hline Authors & Age & Location \\
\hline Stover, 1966 & $\begin{array}{c}\text { Upper } \\
\text { Cretaceous }\end{array}$ & France \\
\hline Perch-Nielsen, 1985 & $\begin{array}{c}\text { Turonian to } \\
\text { Campanian }\end{array}$ & World Wide \\
\hline Jiang and Gartner, 1986 & Cretaceous & Texas \\
\hline Watkins et al., 1998 & Late Albian & Ghana \\
\hline Chira et al., 2004 & $\begin{array}{c}\text { Upper } \\
\text { Cretcaeous } \\
\text { Upper } \\
\text { Cretaceous }\end{array}$ & Romania \\
\hline Lees and Bown, 2005 & \multicolumn{2}{|c}{} \\
\hline
\end{tabular}

Family Microrhabdulaceae Deflandre, 1963

Genus Lithraphidites Deflandre, 1963

Type species : Lithraphidites carniolensis Deflandre, 1963

Lithraphidites praequadratus Roth, 1978

Pl. 1, Fig. 5

Description: Nannoliths, Elongated rod-like with a cruciform or circular crosssection, which have expanded lateral blades. 
Occurrences:

\begin{tabular}{|c|c|c|}
\hline Authors & Age & Location \\
\hline Roth, 1978 & Cretaceous & Atlantic \\
\hline Perch-Nielsen, 1985 & $\begin{array}{l}\text { Campanian to } \\
\text { Maastrichtian }\end{array}$ & World Wide \\
\hline Tantawy et al., 2001 & $\begin{array}{l}\text { Campanian to } \\
\text { Maastrichtian }\end{array}$ & Egypt \\
\hline $\begin{array}{c}\text { Wanderley and Aguiar, } \\
\text { 2006 }\end{array}$ & $\begin{array}{l}\text { Campanian to } \\
\text { Maastrichtian }\end{array}$ & Atlantic \\
\hline
\end{tabular}

Family Polycyclolithaceae Forchheimer 1972

Genus Micula Vekshina, 1959

Type species: Micula decussata Vekshina, 1959

Micula decussata Vekshina 1959

Pl. 1, Figs. 6,7

Description: Nannoliths, four blocky, strongly twisted, wall-cycle elements, joined along sutures which go out to the points of the cube.

Occurrences:

\begin{tabular}{|c|c|c|}
\hline Authors & Age & Location \\
\hline Vekshina, 1959 & Maastrichtian & Siberia \\
\hline Gartner, 1968 & $\begin{array}{c}\text { Upper } \\
\text { Cretaceous }\end{array}$ & U.S.A. \\
\hline Bukry, 1969 & $\begin{array}{c}\text { Upper } \\
\text { Cretaceous } \\
\end{array}$ & U.S.A. \\
\hline Perch-Nielse, 1985 & $\begin{array}{l}\text { Coniacian to } \\
\text { Maastrichtian }\end{array}$ & World Wide \\
\hline Watkins et al., 1998 & Late Albian & Ghana \\
\hline Tantawy et al., 2001 & $\begin{array}{l}\text { Campanian to } \\
\text { Maastrichtian }\end{array}$ & Egypt \\
\hline Chira et al., 2004 & $\begin{array}{c}\text { Upper } \\
\text { Cretaceous }\end{array}$ & Romania \\
\hline Lees and Bown, 2005 & $\begin{array}{c}\text { Upper } \\
\text { Cretaceous }\end{array}$ & Pacific \\
\hline Wanderley and Aguiar, 2006 & $\begin{array}{l}\text { Campanian to } \\
\text { Maastrichtian }\end{array}$ & Atlantic \\
\hline
\end{tabular}

Micula swastica Stradner and Steinmetz 1984

Pl. 1, Fig. 8 
Description: Nannoliths, 4 blocky, strongly twisted, wall-cycle elements, joined along oblique sutures which go out to the points of the cube.

Occurrences:

\begin{tabular}{|c|c|c|}
\hline Authors & Age & Location \\
\hline Stradner and Steinmetz, 1984 & $\begin{array}{c}\text { Upper } \\
\text { Cretaceous }\end{array}$ & Angola \\
\hline Wanderley and Aguiar, 2006 & $\begin{array}{l}\text { Campanian to } \\
\text { Maastrichtian }\end{array}$ & Atlantic \\
\hline
\end{tabular}

Family Prediscosphaeraceae Rood, Hay and Barnard 1971 Genus Prediscosphaera Vekshina, 1959

Type species : Prediscosphaera decorate Vekshina, 1959

Prediscosphaera cretacea(Arkhangelsky,1912) Gartner, 1968

Pl. 1, Fig. 9

Description: Heterococcoliths, elliptical to circular placoliths with two shields and a central-area spanned by cross bars which support tall. The distal shield is typically bicyclic, with a broad outer cycle.

\section{Occurrences:}

\begin{tabular}{|c|c|c|}
\hline Authors & Age & Location \\
\hline Arkhangesky, 1912 & Upper Cretaceous & Russia \\
\hline Gartner, 1968 & Campanian to Maastrichtian & U.S.A. \\
\hline Bukry, 1969 & Upper Cretaceous & U.S.A. \\
\hline Donnaly, 1989 & Upper Cretaceous & Greenland \\
\hline Tantawy et al., 2001 & Campanian to Maastrichtian & Egypt \\
\hline
\end{tabular}

Family Rhagodiscaeae Hay 1977

Genus Rhagodiscus Reinhardt, 1967

Type species: Discolithus asper Stradner, 1963

Rhagodiscus angustus (Stradner, 1963) Reinhardt, 1971

Pl. 1, Fig. 10

Description: Heterococcliths, Loxoliths with a dominant outer-cycle and a centralarea typically filled by a plate of granular calcite. The central structure may be spine-bearing, perforate. The LM image is generally unicyclic. 
Occurrences:

\begin{tabular}{|c|c|c|}
\hline Authors & Age & Location \\
\hline Stradner, 1963 & Upper Cretaceous & Germany \\
\hline Perch-Nielsen, 1985 & Aptian to Maastrichtian & World Wide \\
\hline Tantawy et al., 2001 & Campanian to Maastrichtian & Egypt \\
\hline
\end{tabular}

Family Zygodiscaceae Hay and Mohler 1967

Genus Reinhardites Perch-Nielsen, 1968

Type species: Reinhardites anthrophorus Perch-Nielsen, 1968

Reinhardites sp.

Pl. 1, Fig. 1

Description: Heterococcoliths, Loxoliths with variably-developed inner-cycles and a central-area spanned by a single transverse bar. The central area is not clear, therefore the species left under open name.

Occurrences:

\begin{tabular}{|c|c|c|}
\hline Authors & Age & Location \\
\hline Present work & Late Campanian & Iraq \\
\hline
\end{tabular}

Genus Tranolithus Stover, 1966

Type species: Tranolithus manifrstus Stover, 1966

Tranolithus phacelosus Stover, 1966

Pl. 1, Fig. 12

Description: Heterococcoliths, Loxoliths with variably-developed inner-cycles and a central-area spanned by a single transverse bar. LM image includes both unicyclic and bicyclic types, platelets constitute a transverse bar, and there is a proximal net of lateral bars.

Occurrences:

\begin{tabular}{|c|c|c|}
\hline Authors & Age & Location \\
\hline Stover, 1966 & $\begin{array}{c}\text { Upper } \\
\text { Cretaceous }\end{array}$ & France \\
\hline Perch-Nielsen, 1985 & $\begin{array}{c}\text { Albian to } \\
\text { Maastrichtian }\end{array}$ & World Wide \\
\hline $\begin{array}{c}\text { Wanderley and Aguiar, } \\
\text { 2006 }\end{array}$ & $\begin{array}{c}\text { Campanian to } \\
\text { Maastrichtian }\end{array}$ & Atlantic \\
\hline
\end{tabular}

Incerate Sedis

Genus Ceratolithoides Bramlette and Martini, 1964

Type species : Ceratolithoides kampantri Bramlette and Martini, 1964

Ceratolithoides aculeus Stradner, 1961 


\section{Pl. 1, Fig. 13}

Description: Nannoliths, conical, arrowhead- or horseshoe-shaped nannoliths.

Occurrences:

\begin{tabular}{|c|c|c|}
\hline Authors & Age & Location \\
\hline Stradner, 1966 & Albian & Mexico \\
\hline Perch-Nielsen, 1985 & $\begin{array}{c}\text { Campanian to } \\
\text { Maastrichtian }\end{array}$ & World Wide \\
\hline Lees and Bown, 2005 & $\begin{array}{c}\text { Upper } \\
\text { Cretaceous }\end{array}$ & Pacific \\
\hline
\end{tabular}

\section{Nannobiostratigraphy}

Depending on the stratigraphic distribution of the recorded species, the two following biozones are identified (Fig. 2) :

1- Lithraphidites praequadratus Partial Range Zone (Part) (CC22)

Definition: Interval from first occurrence of Quadrun trifidum Vekshina (1959) to last occurrence of Reinhardites anthophorus (Deflandre, 1959).

Thickness: (10) meters

Boundaries and Discussion: The lower boundary of this biozone is not exposed in the studied area which marked by first occurrence of Quadrun trifidum Vekshina (1959) which did not record recently, the upper boundary is marked by the last occurrence of Reinhardites anthophorus(Deflandre, 1959), or last occurrence of Quadrun trifidum Vekshina (1959) (Bukry and Bramlette, 1970) or the first occurrence of Lithraphidites praequadratus (Roth,1978) or the first occurrence of Lithraphidites quadratus (Verbeek, 1976). The last occurrence of Eiffelithius eximius Stover, 1966 coincided with last occurrence of Reinhardites anthophorus (Deflandre, 1959). The zone is correlated with Quadrun trifidum Biozone of Bukry and Bramlette (1970) which emended by Sissingh (1977) of Late Campanian age.

\section{2- Tranolithus phacelosus Interval Zone (Part) (CC23)}

Definition: Interval from last occurrence of Reinhardites anthophorus (Deflandre, 1959) to the last occurrence of Tranolithus phacelosus Stover(1966).

Thickness: (48) meters

Boundaries and Discussion: The lower boundary is marked by last occurrence of Lithraphidites praequadratus (Roth, 1978). The upper boundary not studied which is marked by last occurrence of Tranolithus phacelosus Stover (1966), that was not determined in this section. This zone correlated with Tranolithus phacelosus zone of Sissingh (1977) which assigned to Latest Campanian age. 


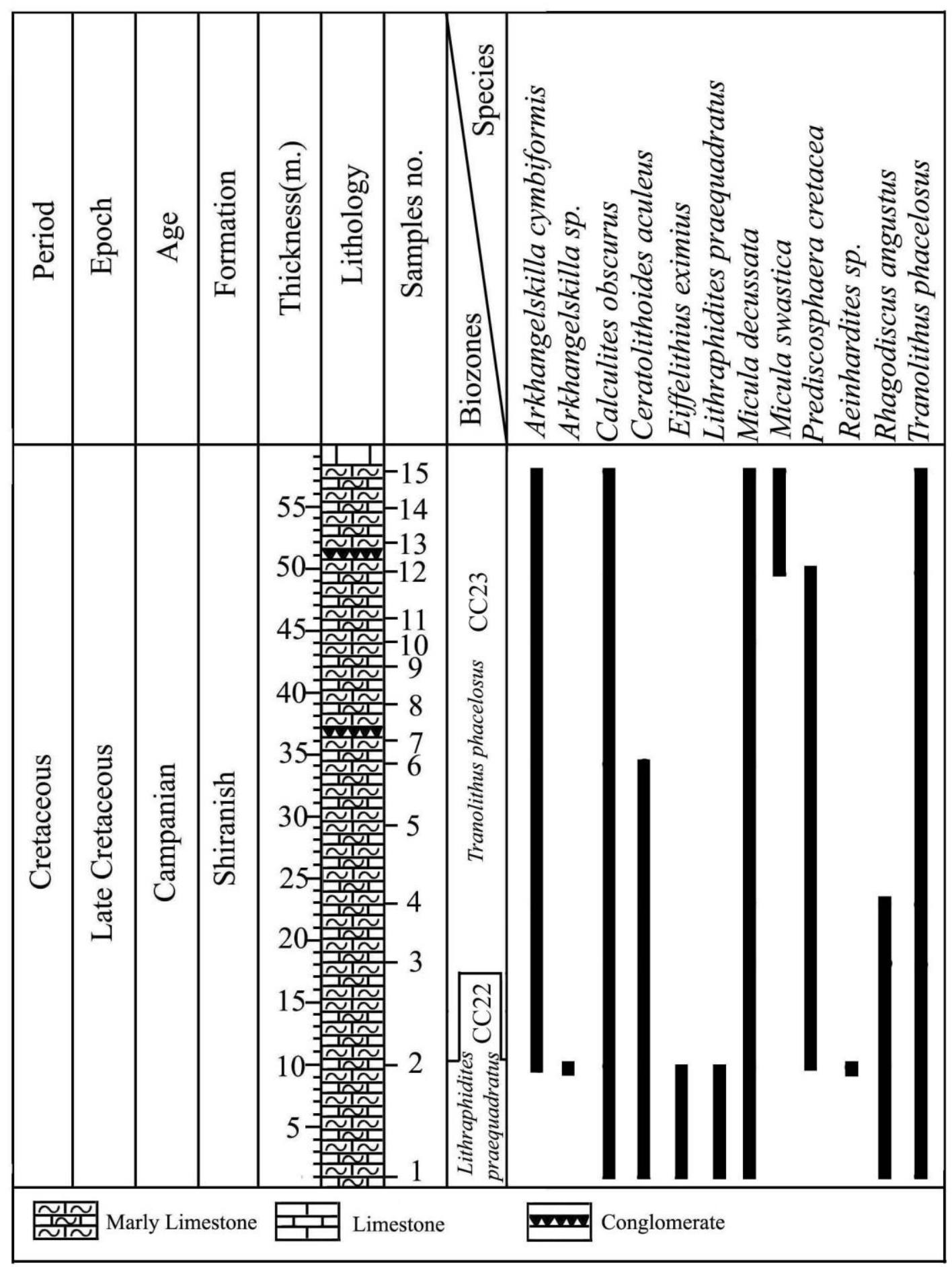

Fig. 2 : Range Chart of Calcareous Nannofossils of the Studied Section. 


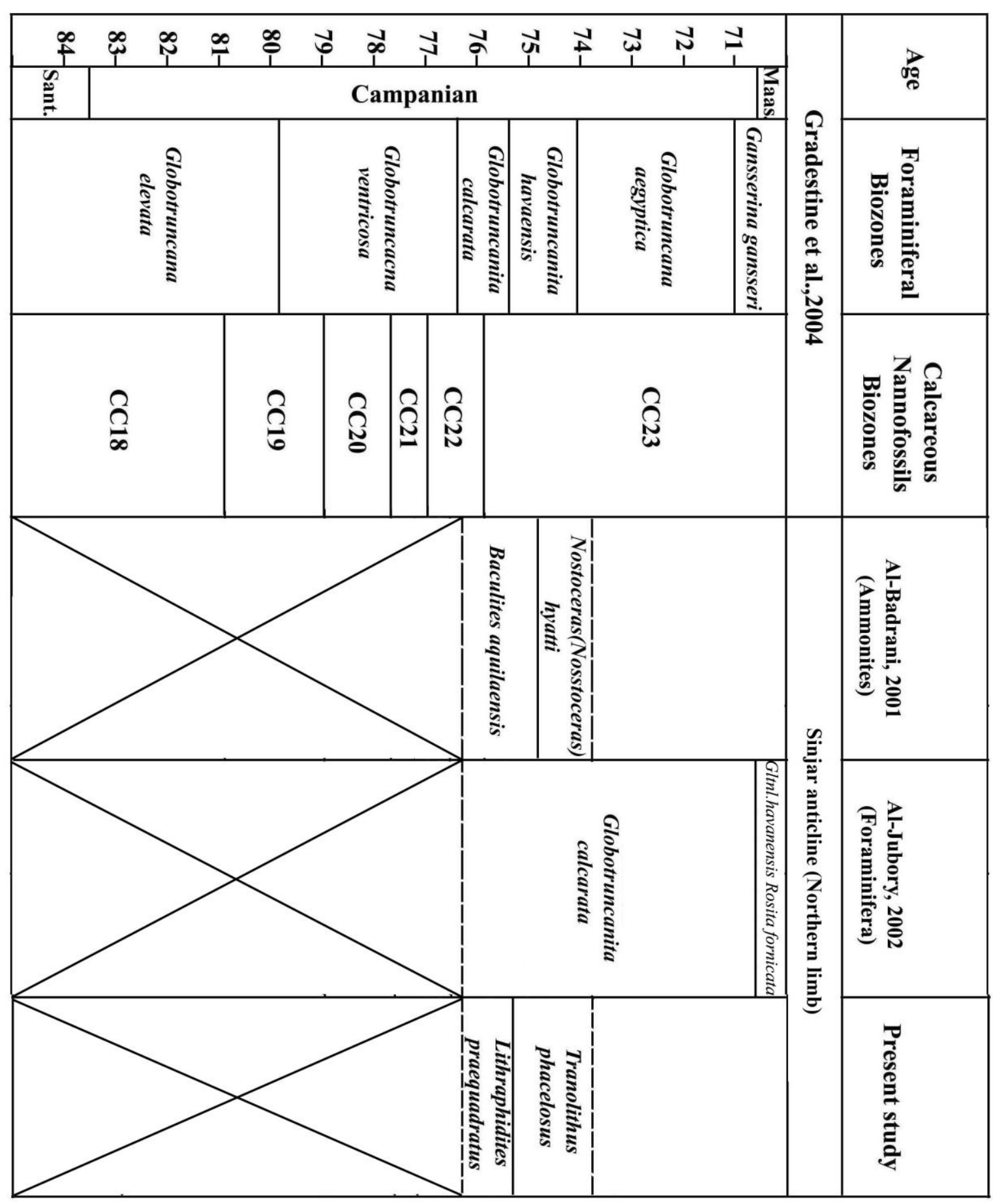

Fig. 3: Chart Showing Campanian Nannobiozones Compared with Iraqi Studies of Ammonites and Foraminifera. 


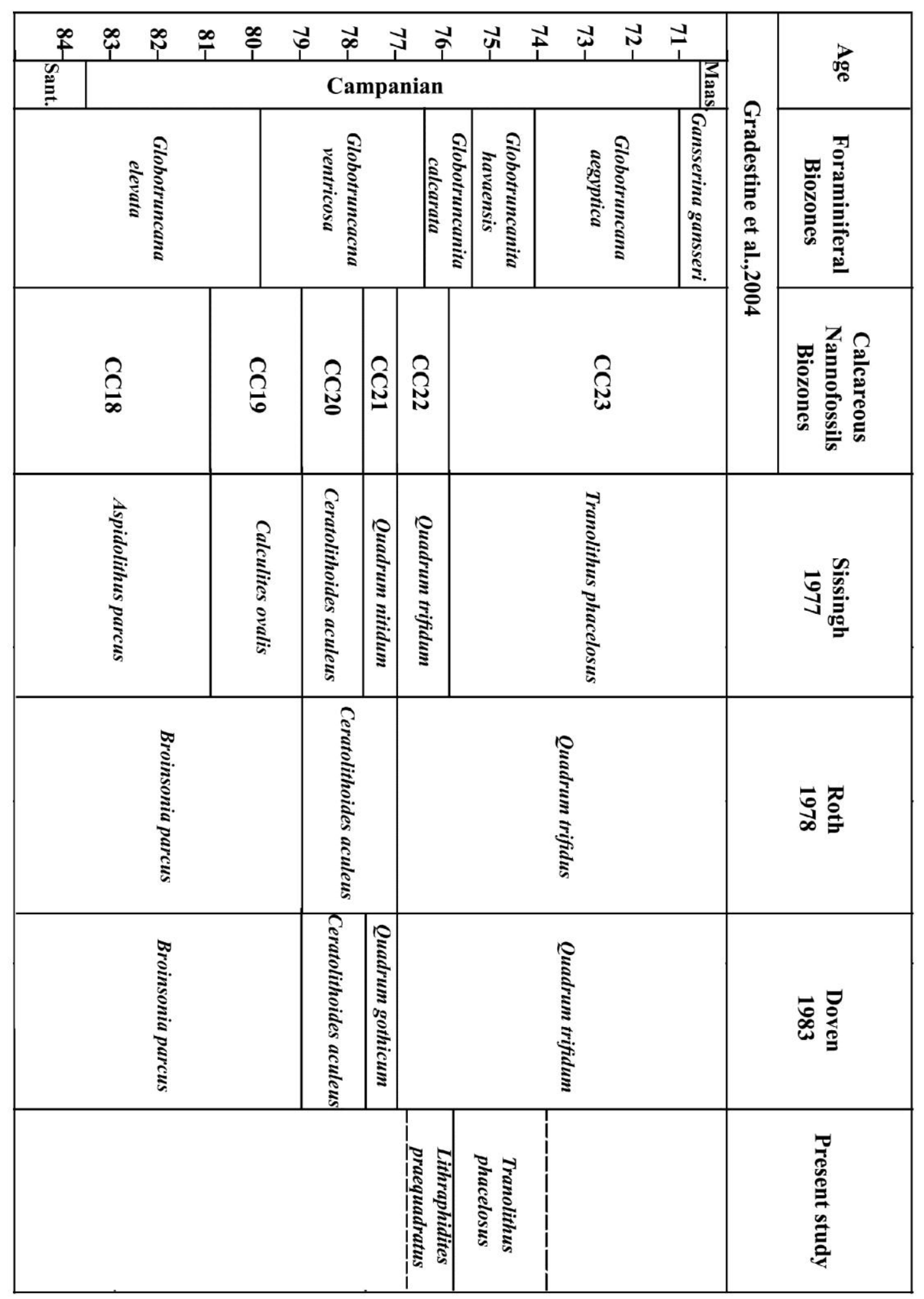

Fig. 4 : Chart Show Campanian Nannobiozones Compared to Regional Studies. 


\section{REFERENCS}

Al-Badrani, O. A., 2001. Biostratigraphy and Paleoecology of Upper Cretaceous Ammonites of the Lower part of Shiranish Formation Northwest of Iraq. Unpublished M.Sc. Thesis, University of Mosul, 104 p. (In Arabic with English abstract)

Al-Jubory, F. N., 2002. Foraminiferal Biostratigraphy and Paleoenvironment of Shiranish Formation in Sinjar area Northwest Iraq. Unpublished M.Sc. Thesis, University of Mosul, (In Arabic with English abstract).

Arkhangelsky, A. D., 1912. Upper Cretaceous Deposits of east European Russia. Mater. Geol. Russ., Vol. 25, pp. 1- 631.

Bellen, R. C. van., Dunnington, H. V., Wetzel, R. and Morton, D. M., 1959. Lexique Stratigraphic International, V. III: Asie, Fasc. 10 a, Iraq. 333 p.

Bramlette, M.N. and Martini, E., 1964. The Great Change in Calcareous Nannoplankton Fossils between the Maestrichtian and Danian. Micropaleontology, Vol. 10, pp. 291 - 322.

Buday, T. and Jassim, S. Z., 1987. The Regional Geology of Iraq. Tectonism, Magmatism and Metamorphism.Vol. 2, S. E. Geol. Surv. Min. Invest. Baghdad, $352 \mathrm{p}$.

Bukry, D., 1969. Upper Cretaceous Coccoliths from Texas and Europe. Univ. Kans. Paleont. Contrib., Protista, art. Vol. 51, pp. 1 - 79.

Bukry, D. and Bramlette, M. N., 1970. Coccolith Age Determination Leg 3, Deep

Sea Drilling Project. Initial Rep. Deep Sea drill.Proj., Vol. 3, pp. 589 - 611.

Chira, C.,Blac, R. and Vulc, A .2004. Cretaceous Calcareous Nannofossils from

Ceru Bacainti Area, Apuseni Mountain, Romania. Acta Paleontologica Romaniae, Vol. 4, 2004. pp. 89 - 96.

Deflandre,G.,1959: Sur les Nannofossils Calcaires et leur Systematique. Rev. Micropalaeontology,Vol. 2, pp. 127 - 52.

Doeven, P. H., 1983. Cretaceous Nannofossils Stratigraphy and Paleoecology of the Canadian Atlantic Margin. Bull. Geol. Surv. Can., Vol. 356, pp. 1 - 70.

Donnaly, D. M., 1989. Calcareous Nannofossils of the Norwegian-Greenland Sea: ODP Leg 104. PODP, Science Results, Vol. 104, pp. 459 - 486.

Gartner, S., 1968. Coccoliths and Related Calcareous Nannofossils from Upper Cretaceous Deposits of Texas and Arkansas. Univ. Kans. Paleont. Contrib., Protista, Art. Vol. 1, pp. 1 - 56.

Gradstein, F. M., Ogg, J. G., Smith, L. J., et al. 2004. A New Geologic Time Scale, with Special Rreference to Precambrian and Neogene. Episodes, Articles, Vol. 27, No. 2 , pp. 83 - 100.

Jassim, S. Z. and Goff, J. 2006. Geology of Iraq. Dolin, Prague and Maravian Museum, Brno, 341 p. 
Jiang, M. J. and Gartner, S. 1986. Calcareous Nannofossils Succession Across the Cretaceous/Tertiary Boundary in East-Central Texas. Micropaleontology, Vol. 32, No.3, pp. 232 - 255.

Lees, J. A. and Bown, P. R., 2004. Upper Cretaceous Calcareous Nannofosils Biostratigraphy ODP leg 198(Shatsky Rise, Northwest Pacific Ocean). Proceedings of the Ocean Drilling Program, Scientific Results Vol. 198, pp. 1 - 60 .

Perch-Nielsen, K. 1985. Mesozoic Calcareous Nannofossils. In Bolli, H. M., Saundes, J. B., and Perch-Nielsen, K. (eds.), Plankton Stratigraphy. Cambridge University Press, Cambridge, pp. 427 - 554.

Roth, P. H., 1978. Cretaceous Nannoplankton Biostratigraphy and Oceanography of the Northwestern Atlantic Ocean. In Bolli, H. M., Saundes, J. B., and Perch-Nielsen, K. (eds.), 1985. Plankton Stratigraphy. Cambridge University Press, Cambridge, pp. 329 - 426.

Sissingh, W, 1977. Biostratigraphy of Cretaceous Calcareous Nannoplankton. In Bolli, H. M., Saunders, J. B., and Perch-Nielsen, K. (eds.), 1985. Plankton Stratigraphy. Cambridge University Press,Cambridge, pp. 329 - 426.

Stover, L. E., 1966. Cretaceous Coccoliths and Associated Nannofosils from France and the Netherland. Micropalaeontology, Vol. 12, pp. 133 - 167.

Stradner, H., 1963. New Contribution to Mesozoic Stratigraphy by Means of Nannofossils. Proceeding of the $6^{\text {th }}$ World Petrol. Congr. Sect. 1, paper 4, pp. 1 - 16.

Stradner, H. and Steinmentz, J., 1984. Cretaceous Calcareous Nannofossils from the Angola Basin, Deep Sea Drilling Project Site 530, Initial Report 75, pp. $565-649$.

Tantawy A. A., Keller, G., Adatte, T., Stinnesbeck, W. and Kassab, A., 2001. Maastrichtian to Paleocene Depositional Environment of the Dekhla Formation, Western Desert, Egypt: Sedimentology, Minerology, and Integrated Micro-and Macrofossil Biostratigraphies. Cretaceous Researches Vol. 22, pp. 795 - 827.

Vekshina, V. N., 1959. Coccolithophoridae of the Maastrichtian Deposits of the West Siberian lowlands. SNIIGGIMS, Vol. 2, pp. 56 - 77.

Wanderley, M. D. and Aguiar, R. P., 2006. Calcareous Nannofossils from Cretaceous/Paleogene Boundary and Earliest Danian of Santo Basin (SAO Palulo Plateu, Brazil) - ODP Leg 39-Site 356-Cores 28/29. Geosciences, Vol. 25, pp. 389 - 401.

Young, J. R. and Bown, P. R. 1997. Cenozoic Calcareous Nannoplankton Classification. Journal of Nannoplankton Research, Vol. 19, pp. 36 - 47. 


\section{PLATE 1}

1- Arkhangelskilla cymbiformis Vekshina, 1959, sample No. 10, polarized transmitted light.

2- Arkhangelskilla sp., sample No. 2, normal transmitted light.

3- Calculites obscurus Deflandre, 1959, sample No. 12, polarized transmitted light.

4- Ceratolithoides aculeus Stradner,1961, sample No. 2, normal transmitted light.

5- Eiffelithius eximius Stover, 1966, sample No.1, normal transmitted light.

6- Lithraphidites praequadratus Roth, 1978, sample No. 1, normal transmitted light.

7- Micula decussata Vekshina, 1959, sample No. 2, normal transmitted light.

8- Micula decussata Vekshina, 1959, sample No. 10, polarized transmitted light.

9- Micula swastica Stradner and Steinmetz, 1984, sample No. 12, polarized transmitted light.

10- Prediscosphaera cretacea Arkhangesky, 1912, sample No. 2, normal transmitted light.

11-Reinhardites sp., sample No. 2, normal transmitted light.

12- Rhagodiscus angustus Stradner, 1963, sample No. 2, normal transmitted light. 13- Tranolithus phacelosus Stover, 1966, sample No. 1, normal transmitted light. 
Plate 1
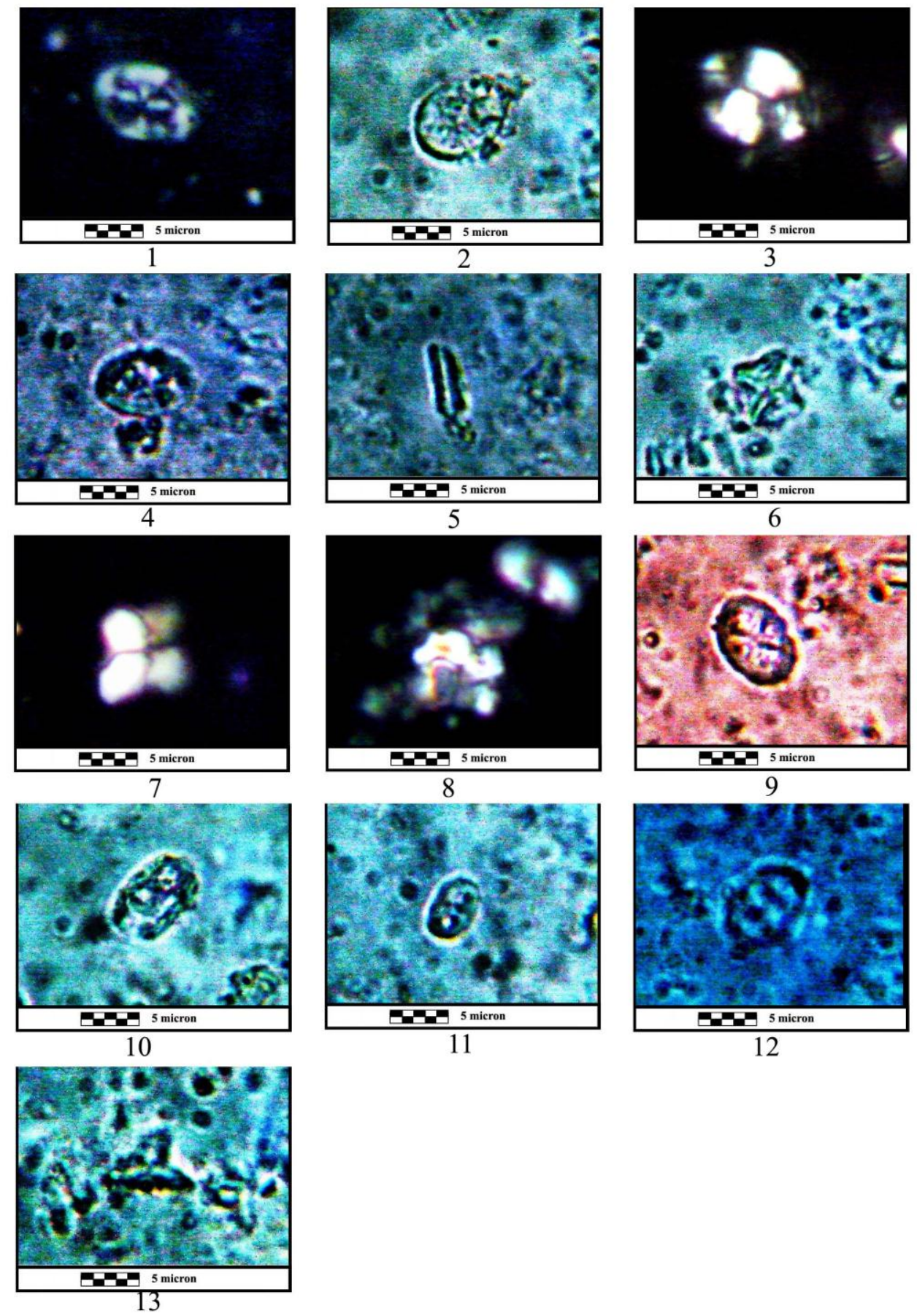